\title{
ระบบการจัดการโลจิสติกส์เพื่อช่วยเหลือผู้ประสบอุทกภัย กรณีศึกษา อำเภอวารินชำราบ จังหวัดอุบลราชธานี
}

\author{
คมสัน โสมณวัตร
}

\section{บทคัดย่อ}

การศึกษาระบบการจัดการโลจิสติกส์เพื่อช่วยเหลือผู้ประสบอุทกภัย กรณีศึกษา อำเภอวารินชำราบ จังหวัด อุบลราชธานี เพื่อ (1) วิเคราะห์กิจกรรมโลจิสติกส์เพื่อช่วยเหลือผู้ประสบภัยในระดับพื้นที่ (Area Base) และ (2) เพื่อ เสนอระบบการจัดการโลจิสติกส์เพื่อช่วยเหลือผู้ประสบอุทกภัยในระดับพื้นที่มีประสิทธิภาพ โดยการเก็บรวบรวมข้อมูล จากแหล่งข้อมูลทุติยภูมิและแหล่งข้อมูลปฐมภูมิ ทั้งข้อมูลเชิงปริมาณจากกลุ่มตัวอย่างชุมชนในอำเภอวารินชำราบ จังหวัดอุบลราชธานี จำนวน 636 คน จากประชากร จำนวน 952 คน และข้อมูลเชิงคุณภาพจากหน่วยงานภาครัฐใน อำเภอวารินชำราบ จังหวัดอุบลราชธานีที่มีส่วนเกี่ยวข้องกับการดำเนินงานในการช่วยเหลือผู้ประสบภัยน้ำท่วม จำนวน 3 หน่วยงาน ผลการศึกษา พบว่า (1) กิจกรรมด้านโลจิสติกส์เพื่อช่วยเหลือผู้ประสบอุทกภัย ทั้งหมด 13 กิจกรรม พบว่า ทั้งพื้นที่ที่มีระบบการจัดการภัยพิบัติและพื้นที่ที่ไม่มีระบบการจัดการภัยพิบัติจะไม่มี กิจกรรมการบริหารถุงยังชีพเพื่อ ช่วยเหลือผู้ประสบภัยและกิจกรรมการบริหารคลังสินค้าและการจัดเก็บในพื้นที่ และ (2) จากการศึกษาระบบการ จัดการโลจิสติกส์เพื่อช่วยเหลือผู้ประสบอุทกภัยเกิดจากการมีส่วนร่วมของชาวบ้านและหน่วยงานภาครัฐที่เกี่ยวข้อง เริ่ม ตั้งแต่การจัดทำแผนปฏิบัติการเพื่อเตรียมความพร้อมรับมือภัยพิบัติ โดยปัจจัยที่ทำให้เกิดกระบวนการมีส่วนร่วมในการ บริหารจัดการโลจิสติกส์ในภาวะอุทกภัย คือ การใช้ประโยชน์จากข้อมูลข่าวสารได้อย่างมีประสิทธิภาพนำไปสู่การขนส่ง และการไหลทางกายภาพที่มีประสิทธิภาพ

คำสำคัญ: ระบบโลจิสติกส์เพื่อช่วยเหลือผู้ประสบอุทกภัย อำเภอวารินชำราบ จังหวัดอุบลราชธานี

* อาจารย์ วิทยาลัยโลจิสติกส์และซัพพลายเชน มหาวิทยาลัยราชภัฏสวนสุนันทา ศูนย์การศึกษาจังหวัดนครปฐม

โทร. 08-1439-6646 อีเมล: sommanawat13@gmail.com 


\title{
Humanitarian Logistics Management system for flooding: Case study Warinchamrab District, Ubon Ratchathani Province
}

\author{
Komson Sommanawat
}

\begin{abstract}
Humanitarian Logistics Management system for flooding: Case study Warinchamrab District, Ubon Ratchathani Province to (1) analyze logistics to help the victims in the area (Area Base) and (2) to provide logistics management system to help flood victims in the area effectively. By collecting data from secondary sources and primary sources. The quantitative data from a sample of community Warinchamrab. Hte number of people out of a population of 636952 people and qualitative data from government agencies in Warinchamrab. Province were involved in the operation to rescue the flood victims of three agencies. The results showed that: (1) logistics activities to help flood victims in all 13 events, both areas with disaster management and space systems for disaster management are. Management activities of relief to the victims and Warehousing and storage space, and (2) of the management system logistics to help flood victims due to the involvement of local people. and the government agencies involved. Since the Action Plan for Disaster Preparedness. The factors that contribute to the processes involved in managing the logistics of the flood is to leverage information more effectively contribute to the transport and flow of physical performance.
\end{abstract}

Keyword: Humanitarian logistics Management system for flooding, Warinchamrab District, Ubon Ratchathani Province

\footnotetext{
* Lecturer College of Logistics and Supply Chain, Suan Sunantha Rachabhat University, Nakhon Pha Thom Education Center Tel. 08-1439-6646 E-mail: sommanawat13@gmail.com
} 


\section{1. บทนำ (Introduction)}

ปรากฏการณ์การเปลี่ยนแปลงของสภาพอากาศ (Climate Change) ส่งผลกระทบการเกิดภัยพิบัติทั่วโลก รวมถึงประเทศไทย [1] จากสถานการณ์น้ำท่วมใน ประเทศไทยตั้งแต่ปี 2548 - 2554 มีความรุนแรงเพิ่มขึ้น และมีการขยายพื้นที่ประสบภัยน้ำท่วมเพิ่มขึ้นเป็นวง กว้าง โดยเฉพาะอย่างยิ่งในเขตพื้นที่ภาคเหนือตอนล่าง และภาคตะวันออกเฉียงเหนือที่ได้รับอิทธิพลจากความ แปรปรวนของสภาพอากาศจากประเทศเพื่อนบ้าน เช่น ประเทศจีน ประเทศเวียดนาม เป็นต้น ประกอบกับสภาพ ภูมิประเทศที่เป็นที่ราบลุ่มสลับภูเขา และมีแม่น้ำหลาย สายไหลผ่าน ทำให้กลายเป็นพื้นที่รองรับน้ำอย่าง หลีกเลี่ยงไม่ได้ ส่งผลให้เกิดความเดือดร้อนแก่ประชาชน ทั้งเรื่องการขาดแคลนที่อยู่อาศัย การเกิดโรคระบาด และ การขาดแคลนเครื่องอุปโภคและบริโภค โดยเฉพาะปัจจัย ที่จำเป็นต่อการดำเนินชีวิต อันได้แก่ น้ำ อาหาร และยา รักษาโรค [2]

ปัจจัยที่ทำให้เกิดความเดือดร้อนแก่ประชาชน นอกเหนือจากภัยธรรมชาติและประชาชนไม่ได้มีการ เตรียมตัวก่อนล่วงหน้าแล้ว ยังเกิดจากการขาดแคลน เครื่องอุปโภคและบริโภคเนื่องจากความยากลำบากใน การขนส่งและการลำเลียงเครื่องอุปโภคและบริโภคของ หน่วยงานทั้งภาครัฐและเอกชน โดยปกติการบริหาร จัดการการลำเลียงหรือการช่วยเหลือผู้ประสบภัยจะ เกี่ยวข้องกับกิจกรรมโลจิสติกส์ เพราะสามารถช่วยให้ เกิดประสิทธิภาพในการให้ความช่วยเหลือที่รวดเร็วและ ลดอัตราเสี่ยงในการเกิดอุบัติเหตุต่อผู้ปฏิบัติงงาน [3] ซึ่ง การบริหารจัดการเพื่อช่วยเหลือผู้ประสบภัยในปัจจุบัน เป็นการบริหารจัดการโดยหน่วยงานจากส่วนกลางเพื่อ กระจายความช่วยเหลือลงสู่ท้องถิ่น ซึ่งมีบริบทด้าน สภาพภูมิประเทศและสังคมที่แตกต่างกัน

กรณีศึกษา อำเภอวารินชำราบ จังหวัดอุบลราชธานี เป็นพื้นที่ที่มีทุนทางพื้นที่ในเรื่องศูนย์กระจายความ ช่วยเหลือของสภากาชาดไทยอยู่ในพื้นที่ที่สามารถ กระจายสิ่งของช่วยเหลือผู้ประสบภัยภายในจังหวัดและ ลำเลียงไปยังจังหวัดใกล้เคียง แต่เนื่องจากการขนส่งและ ลำเลียงสิ่งของสำหรับผู้ประสบภัยยังขาดการบูรณาการ องค์ความรู้ด้านโลจิสติกส์จึงทำให้การขนส่งและลำเลียง
สิ่งของช่วยเหลือผู้ประสบภัยต้องใช้ระยะเวลานานและ อาจก่อให้เกิดต้นทุนในการดำเนินกิจกรรมที่สูงขึ้น

ดังนั้น การศึกษากิจกรรมโลจิสติกส์แบบบูรณการเพื่อ ช่วยเหลือผู้ประสบอุทกภัยในระดับพื้นที่โดยความร่วมมือ ของท้องถิ่นและภาคประชาชนมีส่วนร่วมในการบริหาร จัดการจะทำให้ทราบถึงกิจกรรมด้านโลจิสติกส์ที่เหมาะสม ในการบริหารจัดการการให้ความช่วยเหลือผู้ประสบภัย รวมถึงทำให้ทราบถึง แนวทางหรือปัจจัยในการเพิ่ม ประสิทธิภาพการให้ความช่วยเหลือผู้ประสบภัยเนื่องจาก จะทำให้ผู้ที่มีส่วนเกี่ยวข้องมองเห็นภาพรวมในการ บริหารจัดการการให้ความช่วยเหลือ สามารถออกแบบ ระบบงานของหน่วยงานตามบทบาทหน้าที่ได้เหมาะสม ซึ่งจะเป็นการเพิ่มประสิทธิภาพในการทำงานโดยการลด ต้นทุนและระยะเวลาในการขนส่งลง $[4]$ เพื่อให้ทันต่อ ความต้องการของประชาชนและลดความเสี่ยงในการ กระจายความช่วยเหลือที่ไม่ทั่วถึง รวมถึงความเสี่ยงที่ ผู้ประสบภัยต้องเดินทางมารับของด้วยตัวเอง

\section{2. วัตถุประสงค์}

2.1 เพื่อวิเคราะห์กิจกรรมโลจิสติกส์เพื่อช่วยเหลือ ผู้ประสบภัยในระดับพื้นที่ (Area Base)

2.2 เพื่อเสนอระบบการจัดการโลจิสติกส์เพื่อ ช่วยเหลือผู้ประสบอุทกภัยในระดับพื้นที่ที่มีประสิทธิภาพ

\section{3. การทบทวนวรรณกรรม}

โลจิสติกส์ในการให้ความช่วยเหลือผู้ประสบภัย (Humanization Logistics) หมายถึง การจัดหา กระจาย รักษาสภาพ และทดแทนอุปกรณ์ต่าง ๆ อันได้แก่ น้ำและ สุขอนามัย การติดต่อสื่อสาร และสิ่งปลูกสร้าง แก่ ผู้ประสบภัย เพื่อลดผลกระทบจากการเกิดภัยพิบัติทั้ง ด้านสุขภาพและความปลอดภัย [5] จึงอาจกล่าวได้ว่า โลจิสติกส์มีบทบาทสำคัญในการให้ความช่วยเหลือ ผู้ประสบภัย เนื่องจาก สามารถลดการสูญเสียลงในทันที เนื่องจากมีความยืดหยุ่นสูงและมีการเตรียมความพร้อม เช่นเดียวกับการฟื้นฟูอย่างรวดเร็วที่สามารถเชื่อมโยงกับ การตัดสินใจที่มีประสิทธิภาพ [6]

กิจกรรมโลจิสติกส์เพื่อช่วยเหลือผู้ประสบภัยนับเป็น กระบวนการที่จำเป็นสำหรับการช่วยเหลือผู้ประสบภัย 
และเป็นปัจจัยสำคัญในการเลือกรูปแบบ ความสามารถใน การทำให้เกิดประโยชน์ในสถานการณ์การให้ความ ช่วยเหลือฉุกเฉินอย่างสมบูรณ์แบบต้องอาศัยศักยภาพใน การขนส่งอันหมายถึงต้นทุนการขนส่งที่เพิ่มขึ้น [7] โดย กิจกรรมโลจิสติกส์เพื่อช่วยเหลือผู้ประสบภัยอาจมีได้ หลายรูปแบบ ขึ้นอยู่กับความเหมาะสม บริบทของพื้นที่ สถานการณ์การเกิดเหตุ และความต้องการของแต่ละ พื้นที่ โดยนำหลักการจัดการโลจิสติกส์ทางการค้า กล่าวคือ การคำนึงถึงระยะเวลาในการขนส่งที่รวดเร็ว ด้วยรูปแบบการขนส่งที่เหมาะสม และสินค้าต้องถึง จุดหมายปลายทางอย่างปลอดภัย [8] เนื่องจากมีรูปแบบ ที่แน่นอน โดยอุปสรรคที่เกิดขึ้นด้านข้อมูล ทรัพยากร และบุคลากรที่ไม่เพียงพอ รวมถึงไม่สามารถตอบสนอง ต่อความต้องการการบรรเทาภัยพิบัติจากผู้ประสบภัยได้ ในเวลาที่เหมาะสม เนื่องจากขาดการจัดการที่มี ประสิทธิภาพและการประสานงานที่ดี [2]

ปัจจัยสำคัญที่ส่งผลต่อประสิทธิภาพที่ดีขึ้นของ โลจิสติกส์ในการบรรเทาภัยพิบัติและสินค้าคงคลัง โดย การพัฒนาคลัสเตอร์ช่วยเพิ่มประสิทธิภาพของระบบ ถ่ายเทสำหรับโลจิสติกส์เพื่อช่วยเหลือผู้ประสบภัยและ สินค้าคงคลังเพิ่มขึ้นเกือบสองเท่าเมื่อเทียบกับระบบ ถ่ายเทปกติ ซึ่งเกิดจากปัจจัยสำคัญได้แก่ การมุ่งเน้นที่ กิจกรรม และ ความน่าเชื่อถือของข้อมูลระหว่างสมาชิก ภายในกลุ่มได้ดีขึ้น [9]

ระบบการจัดการภัยพิบัติที่มีหัวใจสำคัญที่การตอบ สนองอย่างรวดเร็วขึ้นอยู่กับชนิดของภัยพิบัติที่เกิดขึ้น จำนวนคนที่ได้รับผลกระทบ ทรัพยากรที่จำเป็นและมีใน ท้องถิ่น รวมถึงความสะดวกสบายในการทำงานในพื้นที่ นอกจากนี้ การมีส่วนร่วมในการขยายระดับการรับรู้ของ ประชาชนที่มาพร้อมกับความรับผิดชอบที่เพิ่มขึ้นของ หน่วยงานท้องถิ่นและองค์กรพัฒนาเอกชนในการ สนับสนุนให้เกิดความคล่องตัวและประสิทธิภาพของ ระบบทั้งหมด [10]

\section{4. วิธีดำเนินการวิจัย}

4.1 ประชากรที่สนใจศึกษาครั้งนี้ แบ่งออกได้เป็น 2 กลุ่ม ประกอบด้วย

(1) หน่วยงานภาครัฐในอำเภอวารินชำราบ
จังหวัดอุบลราชธานี ที่มีส่วนเกี่ยวข้องกับการดำเนินงาน ในการช่วยเหลือผู้ประสบภัยน้ำท่วม จำนวน 3 หน่วยงาน ได้แก่ สถานีกาชาดที่ 7 สำนักงานป้องกันและบรรเทาสา ธารณภัยจังหวัด และเทศบาล

(2) ชุมชนในอำเภอวารินชำราบ จังหวัดอุบล ราชธานี

ตารางที่ 1 จำนวนประชากรและกลุ่มตัวอย่างชุมชนใน อำเภอวารินทชำราบ (ข้อมูล ณ วันที่ 25 มิถุนายน 2556)

\begin{tabular}{|c|l|c|c|}
\hline ลำดับ & \multicolumn{1}{|c|}{ ชุมชน } & $\begin{array}{c}\text { ประชากร } \\
\text { (ครัวเรือน) }\end{array}$ & $\begin{array}{c}\text { กลุ่มตัวอย่าง } \\
\text { (ครัวเรือน) }\end{array}$ \\
\hline 1 & ท่าบ่งมั้ง & 303 & 173 \\
\hline 2 & ดอนงิ้ว & 170 & 120 \\
\hline 3 & ช่างหม้อ & 180 & 125 \\
\hline 4 & คูยาง & 174 & 122 \\
\hline 5 & เกศแก้ว & 125 & 96 \\
\hline & รวม & $\mathbf{9 5 2}$ & $\mathbf{6 3 6}$ \\
\hline
\end{tabular}

4.2 เครื่องมือและคุณภาพเครื่องมือ ประกอบด้วย

4.2.1 แบบสัมภาษณ์เพื่อใช้ในการเก็บข้อมูล หน่วยงานที่เกี่ยวข้องกับระบบการจัดการโลจิสติกส์เพื่อ ช่วยเหลือผู้ประสบอุทกภัย ตามกรอบการระบบการ จัดการภัยพิบัติ

4.2.2 แบบสอบถามเพื่อใช้ในการเก็บข้อมูล ชุมชนในอำเภอวารินชำราบ จังหวัดอุบลราชธานี เกี่ยวกับกิจกรรมโลจิสติกส์เพื่อช่วยเหลือผู้ประสบ อุทกภัย

\section{3 การเก็บรวบรวมข้อมูล}

วิธีการที่ใช้ในการเก็บรวบรวมข้อมูลจะมีการใช้ข้อมูล ทั้งจากแหล่งข้อมูลทุติยภูมิและแหล่งข้อมูลปฐมภูมิ ซึ่ง จะเป็นการเก็บข้อมูลทั้งในเชิงปริมาณ (Quantitative Method) และเชิงคุณภาพ (Qualitative Method) ดังนี้

4.3 .1 การจัดเก็บข้อมูลปฐมภูมิ

โครงการวิจัยจะทำการเก็บข้อมูลปฐมภูมิโดย การสัมภาษณ์เชิงสำรวจ (Explorative Interview) จาก ผู้ที่มีส่วนเกี่ยวข้องกับการขนส่งและกิจกรรมโลจิสติกส์ ในการให้ความช่วยเหลือผู้ประสบภัยในภูมิภาค ร่วมถึง ผู้ที่ได้รับผลกระทบ ทั้งนี้ข้อมูลที่ได้จากการสัมภาษณ์ เชิงสำรวจ (Explorative Interview) จะถูกนำมาใช้ใน 
การออกแบบแบบสอบถาม วิธีการเก็บรวบรวมข้อมูล ปฐมภูมิ แบ่งออกเป็น 3 ส่วน ดังนี้

(1) การสัมภาษณ์เชิงลึก เพื่อเก็บข้อมูล ที่เกี่ยวข้องกับระบบการจัดการโลจิสติกส์เพื่อช่วยเหลือผู้ ประสบอุทกภัยของแต่ละหน่วยงานทีเกี่ยวข้อง โดยการ สัมภาษณ์เชิงลึก (Depth Interview) จากกลุ่มตัวอย่าง แกนนำหมู่บ้าน และหน่วยงานที่เกี่ยวข้อง

(2) การจัด focus group กับกลุ่ม ผู้ประสบภัยน้ำท่วม เพื่อเก็บรวบรวมข้อมูลบริบทของ พื้นที่ศึกษา และผลกระทบที่เกิดขึ้นจากการจัดการ โลจิสติกส์เพื่อช่วยเหลือผู้ประสบภัยในชุมชน

(3) การจัดเก็บข้อมูลจากแบบสอบถาม เกี่ยวกับสถานการณ์และกิจกรรมโลจิสติกส์เพื่อช่วยเหลือ ผู้ประสบอุทกภัยในอำเภอวารินชำราบ จังหวัดอุบล ราชธานี ประกอบด้วย (1) กิจกรรมโลจิสติกส์เพื่อ ช่วยเหลือผู้ประสบภัย และ (2) ระบบการจัดการ กิจกรรมโลจิสติกส์เพื่อช่วยเหลือผู้ประสบภัยในพื้นที่

\subsection{2 การวิเคราะห์ข้อมูล}

(1) การวิเคราะห์ข้อมูลเชิงคุณภาพ จากการสัมภาษณ์เชิงลึกและการจัด focus group ใช้ เทคนิค Content Analysis

(2) การวิเคราะห์ข้อมูลเชิงปริมาณจาก แบบสอบถาม โดยการวิเคราะห์ใช้การประมวลผลข้อมูล ด้วยวิธีทางสถิติ โดยการวิเคราะห์ทางสถิติในการหาความ สัมพันธ์ของตัวแปรจากงานวิจัย

\section{5. ผลการวิจัย}

\section{1 กิจกรรมโลจิสติกส์เพื่อช่วยเหลือผู้ประสบ}

\section{อุทกภัย}

กิจกรรมด้านโลจิสติกส์เพื่อช่วยเหลือผู้ประสบภัย โดยดำเนินการสำรวจกิจกรรมโลจิสติกส์ทั้งหมด 13 กิจกรรม
ตารางที่ 2 กิจกรรมโลจิสติกส์เพื่อช่วยเหลือผู้ประสบภัย อำเภอวารินชำราบ จังหวัดอุบลราชธานี

\begin{tabular}{|c|c|c|}
\hline กิจกรรมโลจิสติกส์ & $\begin{array}{c}\text { พื้นที่ที่มีระบบ } \\
\text { การจัดการ } \\
\text { ภัยพิบัติ }\end{array}$ & $\begin{array}{c}\text { พื้นที่ที่ไม่มีระบบ } \\
\text { การจัดการ } \\
\text { ภัยพิบัติ }\end{array}$ \\
\hline $\begin{array}{l}\text { การติดต่อสื่อสารด้าน } \\
\text { โลจิสติกส์ }\end{array}$ & $\begin{array}{c}\text { สื่อสารหลาย } \\
\text { ช่องทาง }\end{array}$ & สื่อสารทางเดียว \\
\hline การบริการ & มี & ไม่มี \\
\hline $\begin{array}{l}\text { กระบวนการสั่งซื้อ } \\
\text { สิ่งของช่วยเหลือ } \\
\text { ผู้ประสบภัย }\end{array}$ & $\begin{array}{l}\text { กำหนดแหล่ง } \\
\text { จัดซื้อที่สะดวก }\end{array}$ & ไม่มี \\
\hline $\begin{array}{l}\text { การคาดการณ์ความ } \\
\text { ต้องการ }\end{array}$ & ไม่มี & ไม่มี \\
\hline การจัดซื้อ & ซื้อของราคาถูก & $\begin{array}{c}\text { ไม่มีกระบวนการ } \\
\text { จัดซื้อ }\end{array}$ \\
\hline การบริหารถุงยังชีพ & ไม่มีเก็บ stock & ไม่มีเก็บ stock \\
\hline $\begin{array}{l}\text { การบริหารการขนส่งถุง } \\
\text { ยังชีพเพื่อช่วยเหลือ } \\
\text { ผู้ประสบภัย }\end{array}$ & รับที่เทศบาล & รับที่เทศบาล \\
\hline $\begin{array}{l}\text { การบริหารคลังสินค้า } \\
\text { และการจัดเก็บ }\end{array}$ & ไม่มี & ไม่มี \\
\hline $\begin{array}{l}\text { โลจิสติกส์ย้อนกลับ } \\
\text { (Reverse Logistics) }\end{array}$ & มี & ไม่มี \\
\hline $\begin{array}{l}\text { การจัดเตรียมอะไหล่ } \\
\text { และชิ้นส่วนต่าง ๆ }\end{array}$ & มี & ไม่มี \\
\hline $\begin{array}{l}\text { การเลือกที่ตั้งศูนย์ให้ } \\
\text { ความช่วยเหลือ }\end{array}$ & ใกล้ศูนย์อพยพ & ใกล้ศูนย์อพยพ \\
\hline กิจกรรมการเคลื่อนย้าย & $\begin{array}{c}\text { หน่วยงานรัฐ เอกชน } \\
\text { และชาวบ้าน }\end{array}$ & $\begin{array}{c}\text { ชาวบ้าน } \\
\text { เคลื่อนย้ายเอง }\end{array}$ \\
\hline การบรรจุภัณฑ์ถุงยังชีพ & เทศบาล & เทศบาล \\
\hline
\end{tabular}

(1) กิจกรรมการติดต่อสื่อสารเพื่อช่วยเหลือ ผู้ประสบภัย พบว่า พื้นที่ที่มีระบบการจัดการภัยพิบัติมี การสื่อสารที่หลากหลายทำให้ชาวบ้านและผู้ปฏิบัติงานให้ ความช่วยเหลือสามารถเข้าถึงข้อมูลข่าวสารและสามารถ ให้ความช่วยเหลือได้อย่างรวดเร็วกว่าพื้นที่ที่ไม่มีระบบ การจัดการภัยพิบัติ เนื่องจาก พื้นที่ที่ไม่มีระบบการ จัดการภัยพิบัติจะไม่มีการสื่อสารหรือมีการสื่อสารเพียง ช่องทางเดียวทำให้การเข้าถึงข้อมูลการสื่อสารของ ชาวบ้านและผู้ให้ความช่วยเหลือน้อย จึงไม่ทราบความ ต้องการและจำนวนผู้ที่ต้องการความช่วยเหลือเร่งด่วน 
(2) กิจกรรมการบริการเพื่อช่วยเหลือผู้ ประสบ ภัย พบว่า พื้นที่ที่มีระบบการจัดการภัยพิบัติมีความ พร้อมและการให้บริการในการขนย้ายสิ่งของของผู้ประสพ ภัยและการอพยพมากกว่าพื้นที่ที่ไม่มีการจัดการด้านภัย พิบัติ ส่วนการได้รับบริการด้านสุขภาพได้รับในจำนวนที่ ใกล้เคียงกัน กล่าวคือ พื้นที่ที่มีระบบการจัดการภัยพิบัติ จำนวน 49 คน คิดเป็นร้อยละ 11.72 และ พื้นที่ที่ไม่มี ระบบการจัดการภัยพิบัติ จำนวน 47 คน คิดเป็นร้อยละ 17.41 นอกจากนี้ยังพบว่า ในพื้นที่ที่ไม่มีระบบการจัดการ ภัยพิบัติไม่ได้รับบริการสูงถึงร้อยละ 49.63

(3) กิจกรรมกระบวนการสั่งซื้อสิ่งของช่วยเหลือ ผู้ประสบภัย พบว่า พื้นที่ที่มีระบบการจัดการภัยพิบัติมี กระบวนการสั่งซื้อสิ่งของช่วยเหลือผู้ประสบภัยดีกว่า พื้นที่ที่ไม่มีการจัดการด้านภัยพิบัติ โดยพื้นที่ที่มีระบบ การจัดการภัยพิบัติ พบว่า มีการกำหนดแหล่งจัดซื้อ สินค้าที่สะดวกมากที่สุด แต่พื้นที่ที่ไม่มีระบบการจัดการ พบว่าไม่มีกระบวนการสั่งซื้อสิ่งของช่วยเหลือผู้ประสบภัย

(4) กิจกรรมการคาดการณ์ความต้องการความ ช่วยเหลือผู้ประสบภัยในพื้นที่ที่มีระบบการจัดการภัย พิบัติและพื้นที่ที่ไม่มีระบบการจัดการภัยพิบัติ พบว่า ไม่ มีการคาดการณ์ความต้องการความช่วยเหลือผู้ประสบภัย ในพื้นที่คิดเป็นร้อยละ 100

(5) กิจกรรมจัดซื้อสิ่งของเพื่อช่วยเหลือผู้ ประสบภัย พบว่า พื้นที่ทีมีระบบการจัดการภัยพิบัติจะมี วิธีในการจัดซื้อที่หลากหลาย โดยส่วนมากจะจัดซื้อโดย เน้นการซื้อของราคาถูก คิดเป็นร้อยละ 52.87 ส่วนพื้นที่ที่ ไม่มีการจัดการด้านภัยพิบัติ ส่วนใหญ่จะไม่มีกระบวนการ จัดซื้อ มากถึงร้อยละ 60.74

(6) กิจกรรมการบริหารถุงยังชีพเพื่อช่วยเหลือ ผู้ประสบภัยในพื้นที่ที่มีระบบการจัดการภัยพิบัติและพื้นที่ ที่ไม่มีระบบการจัดการภัยพิบัติ พบว่า ไม่มีการเก็บถุงยัง ชีพสำรองเพื่อช่วยเหลือผู้ประสบภัยในพื้นที่คิดเป็น ร้อยละ 100

(7) กิจกรรมการบริหารการขนส่งถุงยังชีพเพื่อ ช่วยเหลือผู้ประสบภัย พบว่า กิจกรรมการบริหารการ ขนส่งถุงยังชีพเพื่อช่วยเหลือผู้ประสบภัยทั้งในพื้นที่ทีมี ระบบการจัดการภัยพิบัติและพื้นที่ที่ไม่มีการจัดการด้าน
ภัยพิบัติ จะบริหารการขนส่งโดยการให้ชาวบ้านมารับที่ เทศบาล ร้อยละ 64.59 และ 51.12 ตามลำดับ

(8) กิจกรรมการบริหารคลังสินค้าและการจัด เก็บในพื้นที่ที่มีระบบการจัดการภัยพิบัติและพื้นที่ที่ไม่มี ระบบการจัดการภัยพิบัติ พบว่า ไม่มีการเก็บถุงยังชีพ เพื่อช่วยเหลือผู้ประสบภัยในพื้นที่คิดเป็นร้อยละ 100

(9) กิจกรรมโลจิสติกส์ย้อนกลับ (Reverse Logistics) ในพื้นที่ที่มีระบบการจัดการภัยพิบัติ พบว่า มีการขนส่งสิ่งของของผู้ประสบภัยกลับที่พัก จำนวน 418 คน คิดเป็นร้อยละ 100 ส่วนในพื้นที่ที่ไม่มีระบบการ จัดการ พบว่า ไม่มีกิจกรรมโลจิสติกส์ย้อนกลับ ทั้งการ ขนส่งผู้อพยพ และ การขนส่งสิ่งของ

(10) กิจกรรมการจัดเตรียมอะไหล่และชิ้นส่วน ต่าง ๆ เพื่อช่วยเหลือผู้ประสบภัย พบว่า พื้นที่ทีมีระบบ การจัดการภัยพิบัติมีการเตรียมอะไหล่และอุปกรณ์ สำหรับการให้ความช่วยเหลือผู้ประสบภัยในด้านต่าง ๆ มากกว่าพื้นที่ที่ไม่มีการจัดการด้านภัยพิบัติ ได้แก่ การ เตรียมยานพาหนะช่วยเหลือผู้ประสบภัย การเตรียม อาหารสำหรับผู้ประสบภัย และการเตรียมที่พักอาศัย/ ศูนย์พักพิงสำหรับผู้ประสบภัย

(11) กิจกรรมการเลือกที่ตั้งศูนย์ให้ความ ช่วยเหลือเพื่อช่วยเหลือผู้ประสบภัยในพื้นที่ที่มีระบบการ จัดการภัยพิบัติ พบว่า กลุ่มตัวอย่างเลือกที่ตั้งศูนย์ให้ ความช่วยเหลือที่ศูนย์อพยพมากที่สุด จำนวน 398 คน คิดเป็นร้อยละ 95.22 และเลือกที่ตั้งศูนย์ให้ความ ช่วยเหลือที่เทศบาล จำนวน 20 คน ร้อยละ 4.78 ส่วนใน พื้นที่ที่ไม่มีระบบการจัดการภัย พบว่า เลือกที่ตั้งศูนย์ให้ ความช่วยเหลือที่ศูนย์อพยพมากที่สุด จำนวน 270 คน คิดเป็นร้อยละ 100

(12) กิจกรรมการเคลื่อนย้ายเพื่อช่วยเหลือผู้ ประสบภัยในพื้นที่ที่มีระบบการจัดการภัยพิบัติ พบว่า แกนนำประสานงานหน่วยงานรัฐและเอกชนให้ยานพาหนะ มากที่สุด ส่วนในพื้นที่ที่ไม่มีระบบการจัดการชาวบ้าน เคลื่อนย้ายกันเองมากที่สุด

(13) กิจกรรมการบรรจุภัณฑ์ถุงยังชีพเพื่อ ช่วยเหลือผู้ประสบภัยในพื้นที่ที่มีระบบการจัดการภัย พิบัติ และไม่มีระบบการจัดการภัยพิบัติ พบว่า เทศบาล เป็นผู้จัดเตรียมมากที่สุด 
5.2 ระบบการจัดการโลจิสติกส์เพื่อช่วยเหลือผู้ ประสบภัยน้ำท่วม

ระบบการจัดการโลจิสติกส์เพื่อช่วยเหลือผู้ประสบภัย น้ำท่วมของอำเภอวารินชำราบ จังหวัดอุบลราชธานี โดย แบ่งตามช่วงเวลาในการให้ความช่วยเหลือเมื่อการเกิดน้ำ ท่วม [11] สามารถแบ่งได้เป็น 3 ระยะคือ

ระยะที่ 1 การวางแผน การเตรียมการ และสภาวะ เมื่อเกิดเหตุฉุกเฉิน

ระยะที่ 2 ระยะเมื่อเกิดน้ำท่วม

ระยะที่ 3 ระยะพื้นฟู

จากการสำรวจและสัมภาษณ์ชาวบ้านและแกนนำ ชุมชนเกี่ยวกับระบบจัดการโลจิสติกส์เพื่อช่วยเหลือ ผู้ประสบภัยเมื่อเกิดอุทกภัย สามารถจำแนกออกได้เป็น 3 รูปแบบ ตามบริบทของพื้นที่ ดังนี้

\section{รูปแบบที่ 1}

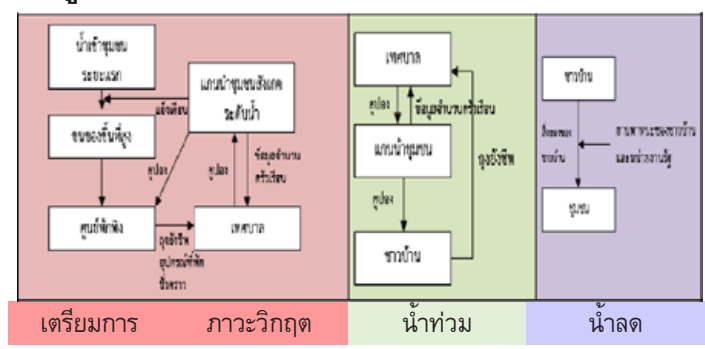

รูปที่ 1 การจัดการโลจิสติกส์เพื่อช่วยเหลือผู้ประสบภัยน้ำ ท่วม รูปแบบที่ 1

มีระบบการจัดการโดยมีคณะกรรมการ/แกนนำชุมชน เป็นศูนย์กลางในการจัดเตรียมข้อมูลทั้งข้อมูลในการเฝ้า ระวัง เช่น ข้อมูลระดับน้ำ ข้อมูลในการอพยพ การเตรียม ความพร้อมให้กับชาวบ้าน รวมทั้งการเป็นตัวกลางในการ สื่อสารระหว่างเทศบาลและชาวบ้านในการรับถุงยังชีพ และความช่วยเหลือต่าง ๆ จากหน่วยงานภาครัฐในพื้นที่

เทศบาลเป็นศูนย์กลางในการบริหารจัดการถุงยังชีพ และอุปกรณ์สร้างที่พักชั่วคราว โดยจะมีการจัดเตรียมถุง ยังชีพและอุปกรณ์สร้างที่พักชั่วคราวให้เพียงพอกับ จำนวนชาวบ้านตามที่แกนนำชุมชนได้แจ้งเข้ามาที่ เทศบาล จากนั้นจึงจัดเตรียมคูปองเท่ากับจำนวนรายชื่อ ชาวบ้านของแต่ละชุมชนให้กับแกนนำชุมชน เพื่อนำไป แจกให้กับชาวบ้านในชุมชนอีกครั้ง เมื่อชาวบ้านได้รับ
คูปองจากแกนนำชุมชนจะนำคูปองมารับถุงยังชีพและ อุปกรณ์สร้างที่พักที่เทศบาลด้วยตัวเอง

\section{รูปบบที่ 2}

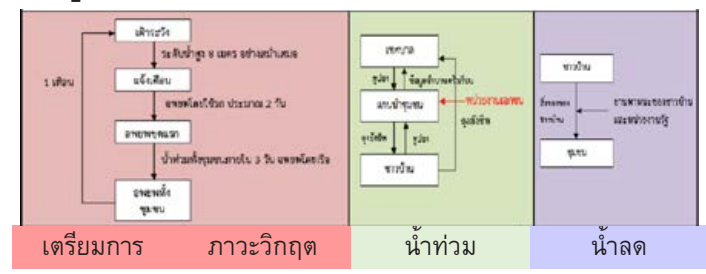

รูปที่ 2 การจัดการโลจิสติกส์เพื่อช่วยเหลือผู้ประสบภัย น้ำท่วม รูปแบบที่ 2

มีระบบการจัดการโดยคณะกรรมการ/แกนนำชุมชน เหมือนกับรูปแบบที่ 1 โดยคณะกรรมการและแกนนำ ชุมชนมีบทบาทหน้าที่ในการเฝ้าระวัง แจ้งเตือนการ อพยพ ประสานงานกับหน่วยงานภายนอก เช่น กาชาด จังหวัด ทหาร ในการให้ความช่วยเหลือเรื่องยานพาหนะ ในการอพยพ โดยมีกระบวนการและขั้นตอนในการอพยพ เป็นลำดับขั้น เนื่องจากลักษณะการท่วมของน้ำไม่เกิดขึ้น โดยฉับพลัน จึงมีระยะเวลาในการเตรียมความพร้อมใน การอพยพ โดยในระยะแรกที่น้ำยังไม่ท่วมจะใช้รถเป็น ยานพาหนะในการเคลื่อนย้าย แต่หลังจากที่น้ำท่วมแล้ว จะใช้เรือทั้งจากชาวบ้านเอง จากกาชาดจังหวัด เทศบาล บริษัทเอกชนที่เข้ามาให้ความช่วยเหลือ

\section{รูแบบที่ 3}

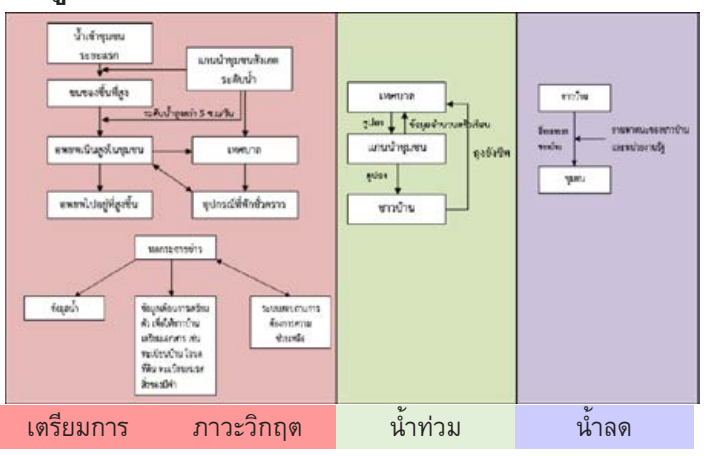

รูปที่ 3 การจัดการโลจิสติกส์เพื่อช่วยเหลือผู้ประสบภัย น้ำท่วม รูปแบบที่ 3

มีระบบการจัดการโดยคณะกรรมการ/แกนนำชุมชน เหมือนกับรูปแบบที่ 1 โดยคณะกรรมการและแกนนำ ชุมชนมีบทบาทหน้าที่ในการเฝ้าระวัง แจ้งเตือนการ อพยพ ประสานงานกับหน่วยงานภายนอก แต่มีระบบ 
สอบถามความต้องการความช่วยเหลือเพิ่ม ระบบช่วยให้ แกนนำชุมชน/เทศบาลทราบความต้องการความช่วยเหลือ ของชาวบ้านและสามารถคาดการณ์และจัดเตรียมสิ่งของ และการให้ความช่วยเหลือได้ถูกที่ ถูกเวลา และตรงตาม ความต้องการของชาวบ้านมากขึ้น

ระบบในการให้ความช่วยเหลือผู้ประสบภัยน้ำท่วม โดยเฉพาะกระจายถุงยังชีพ เทศบาลเป็นศูนย์กลางในการ บริหารจัดการถุงยังชีพ และอุปกรณ์สร้างที่พักชั่วคราว โดยจะมีการจัดเตรียมถุงยังชีพและอุปกรณ์สร้างที่พัก ชั่วคราวให้เพียงพอกับจำนวนชาวบ้านตามที่แกนนำ ชุมชนได้แจ้งเข้ามาที่เทศบาล จากนั้นจึงจัดเตรียมคูปอง เท่ากับจำนวนรายชื่อชาวบ้านของแต่ละชุมชนให้กับแกน นำชุมชน เพื่อนำไปแจกให้กับชาวบ้านในชุมชนอีกครั้ง เมื่อชาวบ้านได้รับคูปองจากแกนนำชุมชนจะนำคูปองมา รับถุงยังชีพและอุปกรณ์สร้างที่พักที่เทศบาลด้วยตัวเอง

\section{6. อภิปรายผล}

การเปรียบเทียบจำนวนกิจกรรมโลจิสติกส์ระหว่าง พื้นที่ที่มีการจัดการภัยพิบัติและพื้นที่ที่ไม่มีการจัดการ ภัยพิบัติ พบว่า พื้นที่ที่มีการจัดการภัยพิบัติมีกิจกรรม โลจิสติกส์เพื่อช่วยเหลือภัยพิบัติมากกว่าพื้นที่ที่ไม่มีการ จัดการภัยพิบัติ แต่กิจกรรมการจัดการโลจิสติกส์ที่ เกิดขึ้นในพื้นที่ศึกษาที่ไม่ได้มีการดำเนินการได้แก่ กิจกรรมการบริหารถุงยังชีพโดยไม่มีการเก็บสำรองถุงยัง ชีพเพื่อช่วยเหลือผู้ประสบภัย และการบริหารคลังสินค้า เพื่อการจัดเก็บ เนื่องจากถุงยังชีพ หรือ สิ่งของเพื่อ ช่วยเหลือผู้ประสบภัยเป็นสิ่งของที่มีอายุการใช้งานสั้น และมีการหมุนเวียนอย่างรวดเร็ว นอกจากนี้ สิ่งของส่วน ใหญ่จะมีการใช้อย่างรวดเร็วในช่วงภาวะวิกฤต จึงไม่มี คลังสินค้าเพื่อเก็บรักษาสิ่งของเพื่อช่วยเหลือผู้ประสบภัย และกิจกรรมโลจิสติกส์เพื่อช่วยเหลือผู้ประสบภัยยังต้องมี การเชื่อมโยงกิจกรรมเข้ากันเป็นระบบเพื่อให้เกิดการ ช่วยเหลือผู้ประสบภัยที่มีประสิทธิภาพ $[4,6]$

ดังนั้น ขั้นตอนการจัดเตรียมการสนับสนุนการ ช่วยเหลือผู้ประสบภัยจำเป็นต้องอาศัยการมีส่วนร่วมจาก ทุกภาคส่วนในพื้นที่ [12 - 14] นอกจากนี้จะต้องมีระบบ การไหลของข้อมูลที่มีประสิทธิภาพ และระบบการ ตอบสนองอย่างรวดเร็วสำหรับความจำเป็นเร่งด่วนของ
การบรรเทาภัยพิบัติขนาดใหญ่ที่ได้รับผลกระทบซึ่งส่วน ใหญ่ประกอบด้วย 3 ส่วนสำคัญ การตรงต่อเวลา ระบบ การขนส่งในภาวะฉุกเฉิน และทฤษฎีการเข้าคิว โดย อาศัยเครือข่ายการขนส่งที่มีบทบาทสำคัญในการส่งมอบ สินค้าในกรณีฉุกเฉินให้กับผู้ได้รับผลกระทบจากภัยพิบัติ ทางธรรมชาติและที่มนุษย์สร้างขึ้น [15]

จากที่กล่าวมาข้างต้น จะพบปัจจัยที่ทำให้เกิดระบบ การจัดการโลจิสติกส์ในภาวะอุทกภัย คือ การใช้ประโยชน์ จากข้อมูลข่าวสาร (Information flow) ได้อย่างมี ประสิทธิภาพนำไปสู่การขนส่งและการไหลทางกายภาพ (Physical flow) ที่มีประสิทธิภาพ สามารถดำเนินการ กระบวนการในการอพยพ และการดำรงชีพได้อย่างมี ประสิทธิผล ไม่ว่าจะเป็นในกิจกรรมการอพยพ ที่มีการ ประสานของความช่วยเหลือด้านพาหนะ มีการเตรียมเก็บ สิ่งของเพื่อการอพยพ กระบวนการแจกถุงยังชีพที่มี ประสิทธิภาพ การแจกวัสดุเพื่อจัดทำที่พักชั่วคราว การ แจกจ่ายอาหาร และการขนย้ายสิ่งของกลับเข้าที่พักเป็น กระบวนการที่มีความสอดคล้องกัน และสามารถ ดำเนินการได้อย่างรวดเร็ว สามารถลดระยะเวลาในการ เคลื่อนย้าย และลดผลกระทบที่เกิดจากการเคลื่อนย้ายที่ ล่าช้า เช่น การบาดเจ็บ สิ่งของสูญหาย เป็นต้น [15]

\section{7. กิตติกรรมประกาศ}

งานวิจัยนี้ได้รับการสนับสนุนทุนจากสำนักงาน คณะกรรมการวิจัยแห่งชาติ และได้รับความอนุเคราะห์ ข้อมูลจากสำนักงานกาชาดจังหวัดอุบลราชธานี สำนักงานสาธารณสุขจังหวัดอุบลราชธานี องค์การ บริหารส่วนจังหวัด องค์การบริหารส่วนตำบล แกนนำ ชุมชน และชาวบ้านในอำเภอวารินชำราบ จังหวัดอุบล ราชธานี ที่ได้ให้ความร่วมมือในการเก็บข้อมูล ซึ่งเป็น ส่วนหนึ่งที่ทำให้รายงานการวิจัยสำเร็จลุล่วง

\section{8. เอกสารอ้างอิง}

[1] Blanc E., Reilly J.M. (2015). Climate Change and Food Situation. Encyclopedia of Energy, Natural Resource, and Environmental Economics, Elsevier Science. Page 22-29. 
[2] Sergio Ricardo Argollo da Costaa, Vânia

Barcellos Gouvêa Camposb, Renata Albergaria de Mello Bandeirab. (2012). Supply Chains in Humanitarian Operations: Cases and Analysis. Procedia - Social and Behavioral Sciences. Vol. 54 No. 4 : $598-607$.

[3] Neal A., Grin M.A., Hart P.M. (2000). The impact of organizational climate on safety climate and individual behavior. Safety Science. vol. 34 No. $1-3: 99-109$.

[4] Wisinee Wisetjindawata, Hideyuki Ito, Motohiro Fujitaa, Hideshima Eizo. (2014) Planning Disaster Relief Operations. Procedia - Social and Behavioral Sciences. Vol. 125 No. $3: 412$ 421.

[5] Tabbara, L. (2007). Revolution of Car Industry: to a Customer Driven Strategy, Implication of Build-to-Order Strategy_Application to RollsRoyce Motor Cars. A Project Report submitted in partial fulfilment of the requirements for the Degree of BSc(Hons) European Logistics Management, School of Applied Sciences. The University of Huddersfield.

[6] Eiichi Taniguchia, Frederico Ferreiraa and Alan Nicholsonb. (2012). A conceptual road network emergency model to aid emergency preparedness and response decision-making in the context of humanitarian logistics. Procedia - Social and Behavioral Sciences. Vol. $39: 307-320$.

[7] Fritz Institute. (2005). Logistics and the effective delivery of humanitarian relief. Fritz Institute, San Francisco, page12.

[8] Ding-Kuo (James) Lu, Stephen Pettit,Anthony Beresford. (2006). Critical Success Factors for Emergency Relief Logistics. WHAMPOA - An Interdisciplinary Journal. vol. 51 No. 1 : 177-184.
[9] Nur Budi Mulyonoa*, Yoshiteru Ishidab. (2014) Clustering inventory locations to improve the performance of disaster relief operations. Procedia Computer Science. Vol. 35 : 1388 1397

[10] Ramazan Kaynak, Ahmet Tuğrul Tuğer. (2014) Coordination and collaboration functions of disaster coordination centers for humanitarian logistics. Procedia - Social and Behavioral Sciences. Vol.109 No. 8 : 432 - 437.

[11] Sander de Leeuw, Iris F.A. Vis and Sebastiaen N. Jonkmon. (2012). Exploring Logistics Aspects of Flood Emergency Measure. Journal of contingencies and crisis Management. Vol. 20 No. 3 : 166-179.

[12] ทวีทอง หงส์วิวัฒน์. (2537). การมีส่วนร่วมของ ประชาชนในการพัฒนา. กรุงเทพมหานคร ศักดิโสภาการพิมพ์

[13] ทนงศักดิ คุ้มไข่น้ำ. (2534). การพัฒนาชุมชนเชิง ปฏิบัติ. กรุงเทพมหานคร : บพิธการพิมพ์.

[14] วิฑูรย์ ปัญญากุล. (2535). การพัฒนาต้องมาจาก ประชาชน. พิมพ์ครั้งที่ 2 . กรุงเทพมหานคร : สถาบันชุมชนท้องถิ่นพัฒนา.

[15] Xinhua Hea Wenfa Hub Jia Hao Wu and Chuanxu Wanga. (2013). Improving Emergency Goods Transportation Performance in Metropolitan Areas Under Multi-Echelon Queuing Conditions. Procedia Social and Behavioral Sciences. Vol. 96 No. 6 : $2466-2479$. 